\title{
Food service in the scientific field of Food and Nutrition: Reflections about scientific conceptions and research
}

\author{
Alimentação coletiva no campo científico da \\ Alimentação e Nutrição: reflexões sobre \\ concepções científicas e pesquisa
}

Flávia Milagres CAMPOS

Shirley Donizete PRADO ${ }^{1}$

Francisco Romão FERREIRA ${ }^{1}$

Fabiana Bom KRAEMER ${ }^{1}$

\section{A B S T R A C T}

Supported by the categories of capital and scientific field of Bourdieu, this paper aims to situate, in the Food and Nutrition field, the core of knowledge and practices here called food service, and to provide evidence that the agents that operate in this core acknowledge that their quantum of scientific capital is insufficient to maintain distinct positions in the field. Realizing their lack of prestige in the scientific field, some of these agents seek to redirect their activities, traditionally focused on the labor market, aiming to participate in graduate programs, since that is where institutionally recognized scientific research occurs. The outline of an approaching movement with the world of research is recognized in this core. This discussion proposes a reflection on the image of science that anchors food service research and the challenges related to the current conditions for scientific practice in Brazil. This essay discusses the framing in the hegemonic research model, based on the natural sciences. We questioned the adoption of a single way of research, since food service has multifaceted aspects, which demands epistemological plurality.

Keywords: Collective feeding. Food services. Knowledge. Science.

Apoiado nas categorias de campo e capital científico de Bourdieu, o presente trabalho busca situar o núcleo de saberes e práticas, aqui denominado alimentação coletiva, dentro do campo da Alimentação e Nutrição,

\footnotetext{
1 Universidade do Estado do Rio de Janeiro, Instituto de Nutrição, Programa de Pós-Graduação em Alimentação, Nutrição e Saúde. R. São Francisco Xavier, 524, Pavilhão João Lyra Filho, $12^{\circ}$ Andar, Bloco E, Sala 12.007, 20559-900, Rio de Janeiro, RJ, Brasil. Correspondência para/Correspondence to: SD PRADO. E-mail: <shirley.donizete.prado@gmail.com>.
} 
bem como apresentar elementos que mostram que os agentes atuantes nesse núcleo reconhecem como insuficiente seu quantum de capital científico para manter posições mais distintas no campo. Percebendo-se desprivilegiados no campo científico, parte desses agentes busca redirecionar suas atividades, tradicionalmente voltadas para o mercado de trabalho, com o fito de participar de programas de pós-graduação, já que estes se configuram como local institucionalmente reconhecido da pesquisa científica. Esboça-se um movimento no sentido de aproximar mais esse núcleo do mundo da pesquisa. A partir dessa discussão, busca-se refletir sobre a imagem de ciência que ancora a pesquisa na alimentação coletiva e os desafios que se colocam ante as condições atualmente estabelecidas para a prática científica no Brasil. Problematiza-se, neste ensaio, o enquadramento no modelo hegemônico de pesquisa, calcado nas ciências da natureza. Questiona-se a adoção de uma única forma de pesquisar no âmbito da alimentação coletiva que, frente ao seu caráter multifacetado, demanda abordagens pluriepistêmicas.

Palavras-chave: Alimentação coletiva. Serviços de alimentação. Conhecimento. Ciência.

\section{INTRODUCTION}

Enjoying widespread social acceptance, science becomes increasingly legitimate as an almost unquestionable parameter for a large part of the decisions made by society today. From the concepts of scientific field and capital ${ }^{1,2}$ of Pierre Bourdieu, this study aims to discuss some aspects of the scientific research conducted in the scope of Food and Nutrition, specifically of food service. The choice of research as focus of the reflections made herein stems from its importance in academia and its current valorization in a wider political and economic context.

The notion of scientific field covers the idea of a structured and structuring space where the relationships between researchers occur. These relationships regard the dispute for the ability to speak legitimately in the name of science. However, this dispute is not balanced since each agent accumulates along his trajectory a different volume of recognition and prestige before other agents, according to the type of academic product that is most valued by the field at any given moment. This is what Bourdieu calls scientific capital. Scientific practice is oriented towards the acquisition of this capital, which exerts a symbolic effect and ranks the researchers in the field ${ }^{1}$.

This is how Food and Nutrition is understood as a field, where scientific interests (which always carry intellectual and political aspects) remain in constant dispute. In this field different spaces are established, which are called herein core of knowledge and practices, characterizing a concentration of knowledge that unfold in specific skills ${ }^{3}$. In this study, the interest lies in the knowledge core herein identified by the denomination food service, which deals with the production and distribution of meals to groups of people in many types of establishments. Hence, its locus of action covers food services called, in some Brazilian spaces, meal production units ${ }^{4}$ and in others, food and nutrition units ${ }^{5}$.

This core can be considered one of the pillars of the field of Food and Nutrition, present from the onset of the profession of dietician in Brazil6. However, what seems to manifest today in the field is a certain lack of prestige of food service with respect to scientific practice and the training of researchers, considering its limited participation in graduate programs, known as stricto sensu in Brazil7. On the other hand, this study presents and discusses the movement of part of the agents that work in this core to construct and accumulate scientific capital.

However, we question the attempt of these agents, who in the search for legitimacy, try to accumulate scientific capital by approximating what is practiced hegemonically in Food and Nutrition studies. These studies privilege the biological aspect of the act of eating ${ }^{8}$ and try to suit itself to the current scientific production regime imposed by the country's current education and science and technology policies, which establish increasingly higher productivity requirements, disregarding the differences in the research methods proper of many knowledge spaces $^{9}$. 
The discussion proposed herein is considered to be of national interest given the specificity of the historic process of the constitution of food service in Brazil, bound to a project of modernization that began in the 1930s, based on the country's urbanization and industrialization ${ }^{6,10}$. Hence, this reflection is undertaken in relation to some conceptions about science in order to develop the argument that, in the field, a vision of scientificity based on logic and experimental method stands out. Such vision disregards the need of other approaches and has been pursued by part of the food service agents as the path to its insertion and consolidation in the prestigious world of science.

\section{Food service: scenario and movements}

This study made a qualitative approach, and the investigative techniques included secondary data ${ }^{7}$ and participant observation ${ }^{11}$ of the III Brazilian Congress of Food Service. The information recorded in the field diary was analyzed to map the main subjects discussed in the congress and to establish relationships with political and epistemological scenarios.

In the development of the field of Food and Nutrition in Brazil, the nutrition-related studies, especially those related to primary and clinical research and epidemiological approach have already reached notoriety and prestige in the disputed world of science. The field is also being consolidated politically as indicated by the dismembering of the assessment area Nutrition in the Coordenação de Aperfeiçoamento de Pessoal de Nível Superior (Capes, Coordination for the Improvement of Higher Education Personnel), which was until then subordinated to Medicine?.

In the case of food service the situation is different. A survey conducted in 2009 found only five research lines in the graduate programs of the assessment area Nutrition in Capes conducting studies on food services, while the core of Food and Nutrition in Public Health had
29 research lines, Primary and Clinical Nutrition had 24 lines, and Nutrition and Foods had 11 lines $^{7}$. Even if these data do not represent all the studies, they indicate that food service is delayed with respect to the institutionally most important research, historically centered in the graduate studies.

In parallel to these indications, some issues stood out during the congress. Many lectures suggested a general feeling that this core needs to get stronger. This feeling may be translated as the need of obtaining recognition in the field of Food and Nutrition, since the agents perceived themselves being discriminated in this social space. Comments such as, "even professors of the area are discriminated", or "the objective [of the debates] is to value the professional and prove that there is research, knowledge, in this area"12 evidence the search for legitimacy. The agents found themselves in a lower position in the field, identifying the need of increasing their symbolic capital. According to Bourdieu:

The symbolic capital - another name of the distinction - is nothing but capital, regardless of species, when perceived by an agent with perception categories resulting from the incorporation of the structure of its distribution, that is, when known and acknowledged as somewhat obvious (p.145) $)^{13}$.

However, symbolic recognition ends up becoming an objective advantage, which in the scientific field means greater opportunities to obtain grants and publish studies, for example. Nevertheless, it is important to clarify that the presentation of these elements does not mean seeing food service as a victim in the competition within the field, on the contrary, it is necessary to delimit the space and time where a shortage of capital is perceived because in other times (throughout the history of nutrition) and in other circles (politics, labor market), food service had already occupied positions of greater power ${ }^{14}$. But, regarding the scientific field and the properties that are "pertinent and efficient in the considered 
game" (p.107) ${ }^{15}$, the agents of this core feel deprived of distinction and power, both in material and symbolic terms.

On the other hand one cannot ignore that the rules of this game are not consensual but established and supported by those who benefit from them. Hence, the thesis of shortage of scientific capital of this core can only be presented when one considers the value that research assumed in academia and the indicators currently used for qualifying researchers, graduate programs, and institutions, even if one cannot avoid criticizing them ${ }^{16,17}$

The Forum of Coordinators and Professors of the Food Service Area occurred during the congress, and it was possible to follow it. The discussions of the forum that stood out were: a) the need of events to improve professional visibility; b) the importance of disseminating scientific studies; c) adoption of a political position for the creation of professional master programs, and $d$ ) the need of qualifying professors for the production of scientific knowledge and the training of researchers. The inadequate number of research lines, supervisors, and journals to publish the studies produced by this knowledge core was pointed out as a substantial limitation. The transposition of such barriers imposes, according to the forum participants, investments in the training of doctors and their insertion in graduate programs, without which it is not possible to obtain research grants.

Perception of the existence of a type of "academic imbroglio" results in a migration to other areas of knowledge; this phenomenon can be well identified in the words of one of the individuals present in the meeting as he subtly observed that the food service professor who manages to get grants in other areas sometimes "becomes dazzled and goes away"18. In this case it concerns the movement of researchers through the areas of knowledge, as they are institutionalized in the sponsoring agencies (e.g., Food Science and Technology), to guarantee a better return to their scientific investments, even if they continue to maintain an interface with the food service core.

It is clearly acknowledged that the core is not homogeneous. However, considering that it is a national event, the discussions held within it are coordinated with the demands of a significant part of the agents of the core being focused on. Hence, it seems reasonable to say that part of the food service agents, especially those linked to academia, identify both the lack of prestige of the core with respect to research and the importance that research has gained today, and point out the need of dedication to this issue in order to improve its position in the field. In this case, adequacy, even if partial, to the current model of scientific knowledge production seems unavoidable.

\section{Approximation with research}

Although it is not part of the scope of this study to discuss the country's current model of scientific production and the form of assessment of its quality, which has been done by other actors $^{9,19,20}$, these two aspects have a fundamental role in the present discussion and require minimum description. In Brazil the production of scientific knowledge is concentrated in the public university, especially in graduate programs, incentivized by Capes and sponsored by the Conselho Nacional de Desenvolvimento Científico e Tecnológico (CNPq, National Council for Scientific and Technological Development), in addition to regional support from state researchsponsoring agencies. Assessment of the graduate programs, researchers, and ultimately, of the research projects linked to them is based on productivity, which in turn is increasingly based on the publication of scientific articles. The sponsoring agencies distribute grants based on scientific production, generally assessed by bibliometric methods. These are based on the database of the Lattes Platform of CNPq, which aggregates data about researchers, and in Capes' Qualis system, which classifies and ranks scientific journals. 
It is in this social space that some agents of the knowledge core of food service aim to insert themselves. In parallel to the restlessness related to the lack of acknowledgment by the peers, food service ponders about the need and possibility of leveraging research to ensure competitiveness in the field, as can be seen in the congress and especially in the Forum of Coordinators and Professors of the area. This interest in research reflects a search for legitimacy, which in this case would be in science. This core has historically focused on the labor market (considering its participation with respect to professional insertion ${ }^{21}$, its relationship with the industrialization process of the country, and its participation in labor unions). However, the appreciation of science and changes in the organization of public universities, whose discourse is based on the dyad teaching and research, but in practice prioritizes the latter ${ }^{9}$, has imposed a new scenario.

Currently, in universities and in many cases, elsewhere, research generates recognition. Research has become an institutional requirement, contemplated also with financial incentives (such as productivity grants) and corresponding symbolic return. Along with this process the number of graduate programs in the assessment area of nutrition has grown from five to twenty-five between 1995 and 201422, indicating a maturation of research in this field. Thus, the discussions seen at the congress manifest an attempt of food service, even if very incipient, of organizing itself institutionally, politically, and intellectually, in order to participate in the consolidation of the social spheres of knowledge production and graduate training in Food and Nutrition.

However, the insertion in this process first requires convincing everyone that what is done in food service is scientific. Still regarding the congress, comments such as "We do not have theoretical construction ... We came from common sense ... It is necessary to break the barrier of lack of visibility ...", suggest a concern with rationalizing the practices of dieticians inserted in food service. This occurs because the work that is performed in food services by dieticians is often seen as not very specific and disqualified. Food service practice cannot be analyzed without considering the scenario in which it is inserted, that is, an urban, capitalist, and industrial society, whose structure of production and labor organization focuses on the accumulation of capital. However, practice in a food service has an intense administrative aspect, which includes activities such as contact with suppliers, inventory control, calculation of costs, human resources selection and supervision, and customer service. These activities hinder the identification of food service practice with the work of a dietician as a health professional and at the same time can require the execution of simple tasks that do not require a professional with higher education ${ }^{23}$. Proximity with common knowledge, in this case, linked to culinary, reinforces the idea of detaching from science. To work around this situation, there is an attempt to objectify the dietician's food service practices.

However, there seems to be an identification of science with a specific type of objectivity, which is centered in the scientific method. This does not escape from what happens in other knowledge cores of the Food and Nutrition field. The need of becoming "more scientific" is linked to a certain ideal of scientificity, which ends up disqualifying practice in food service, since it refuses that which is not based on what is considered scientific evidence.

\section{Science and scientific method}

The prevalence of the biological perspective in the field of Food and Nutrition is linked to the adoption of scientific methodologies with experimental or empirical emphasis ${ }^{7,24}$. This perspective is often associated with an image of science as a practice capable of revealing the truth of the facts as it uses the scientific method, which purifies the reality of its contradictions. Two 
principles present in the manifest of the Circle of Vienna (a) experience is the source of all knowledge, and (b) logical analysis is the preferential method for solving philosophical problems $\mathrm{s}^{25}$ - in a way prevails in the imaginary of the students, professors, and professionals of the field. Even if the criticisms and attempts to overcome the limitations of this vision have not necessarily led to the "truth", it pays to recall, even if rapidly, some authors that presented other looks upon science.

Popper ${ }^{26}$, for example, affirmed that one cannot guarantee that a certain scientific theory is true because nobody knows whether it will be proven false one day. On the other hand, he proposes the use of rational criticism. If the sources cannot guarantee the validity of knowledge, the objective criticism of the theories is what would characterize science. However, there is still the issue regarding which criterion would be used to carry out this rational criticism. If the criticism is based on observation and logic, could it not also incur in error since there would be no way of ensuring that the observations were not wrong? Regardless of this questioning, Popper's proposal, at least, shakes the idea of science as a generator of absolute truths.

In a different perspective, Kuhn ${ }^{27}$ suggests that science develops in stages. In a given moment there would be what he calls "normal science", which works within a paradigm and in simpler terms, may be understood as a set of premises that scientists share. However, anomalies that do not find answer within this paradigm start a crisis that leads to a revolution, with the appearance of new theories incompatible with the existing references and the establishment of a new paradigm. In Kuhn's view, one could say that the biomedical paradigm predominates in the field of Food and Nutrition, guiding academic education, professional practice, and research (guiding, for example, the selection of problems that deserve to be studied and the appropriate methods), despite perceived anomalies and disagreeing voices. An example would be Kraemer et al. ${ }^{28}$, who make a discussion based on theoretical subsidies of the social sciences and humanities to better understand diet as an interstitial theme that links the biological and psychosocial aspects.

However, Kuhn's proposal is too ordered and ambitious to explain scientific progress in any time. Nevertheless, his thesis incorporates historic and sociological aspects to the notion of science. According to him, "... this issue of paradigm choice can never be unequivocally settled by logic and experiment alone ..." (p.128)27. A paradigm, and therefore, the scientific theories and premises, do not survive only because they are intellectually better, but they also depend on the social relationships that unfold during history.

In turn Bourdieu² points out that it is not enough to describe the social context and relate it directly to the facts because it is through the scientific field, which relies on its own social laws, that the global social context influences the researchers. One example would be the widespread interest of studying soybeans in the field of Food and Nutrition a few years ago. This interest cannot be analyzed only based on the results of experiments about the nutritional value of soybeans, since it is part of a network that involves governments, agricultural production, food industry, and malnutrition indices to say the least, which act on researchers' choices according to the rules of the field, that is, according to what brings the greatest return in the form of scientific capital.

As pointed out in the beginning of this section, in the field of Food and Nutrition, the studies are based predominantly on experiments, and there is a general appreciation for knowledge produced in laboratories, following the trend of the biomedical area. However, since good results depend on experiments performed by competent researchers and the criterion used for determining the researcher's competence is exactly analysis of the results, the problem is a loop and the experimental proof ceases to be enough to settle scientific controversies. Thus, the certification of 
new knowledge requires the use of negotiation tactics, often not scientific ${ }^{29}$.

Latour $^{30}$ also discusses the issue of negotiation in scientists' persuasion strategies. As he considers that the construction of scientific facts is a collective process, he assumes that it is not possible to know right away whether something claimed by a researcher is indeed a fact or fiction. This is defined by the later use of what was said. Hence, researchers use articles, documents, and alliances with researchers of other fields and societal sectors to support their claims and force them to be taken as fact, that is, incorporated by other researchers. For example, there are as many scientific arguments for and against the safety of transgenic foods. Both sides will use more than just experimental results to impose themselves scientifically, making use of allies with common interests in the result of the controversy.

While none of the arguments discussed until now seems to offer a universal explanation for the establishment of scientific knowledge, they undo two notions: that scientific objectivity would be linked to an impersonal practice and that there would be a method capable of guaranteeing this objectivity and revealing accurately how the world works.

\section{Other possibilities}

If there is no single model, a sequence of particular steps and rules that guide scientific studies, Feyerabend ${ }^{31}$ proposes considering many different methods valid. Given the endless heterogeneity of the human experience, any methodological model ends limitations, which justifies the non-use of an exclusive model or a specific approach in all situations. Even a methodological approach that is appropriate for some domains can be inappropriate for others, restricting hypotheses and possibilities, and even the criteria used for defining the types of data considered acceptable ${ }^{32}$.
The methodological plurality seems like a more interesting bet, since it holds the possibility of guiding studies according to the characteristics of the problems of interest. Back to the core of food service, one can say that it has a multidisciplinary aspect, hindering the possibility of fit its research options in the biomedical model.

The production of meals involves the theoretical, scientific, and cultural dimensions ${ }^{4}$. Knowledge from distinct areas mix up, like chemistry and biology in the natural sciences domain and administration, in the humanities domain, and possibly culinary knowledge and the social aspects of food, here understood as different from nutrition.

Food service develops its practices in a space that is much less simple than it looks. For example, focusing only on the administrative aspects and considering that management cannot be reduced to a technique to reach objectives but to a social practice, to settle the contradictions and conflicts that are inherent to the practices employed to reach such objectives ${ }^{33}$, an important component is added that complicates food service activities. This perspective alone would be enough to justify the need of not restricting scientific research to certain methodological postures in order to avoid limiting conceptions about the phenomena and possible solutions to the challenges.

What is usually done to deal with a complex reality is to separate it in parts, simplify it. However, the whole is more than the simple addition of the parts, since it may affect the parts and be affected by the parts, giving rise to new properties in the whole, which in principle were not present in the parts ${ }^{34}$. Conducting studies that attempt to separate each component involved in the practice of food service, isolating them definitely, without verifying the connections between the components, will hardly be useful for dealing with the problems that arise. Studies done in laboratories or epidemiological studies can be useful for answering certain questions, but 
inadequate if we consider a particularity of the core, which is the need of a study that is strongly linked to professional practice.

Even if the hegemonic model of nutrition research allowed and allows the acquisition of scientific knowledge, if the core of food service is already multidisciplinary with respect to the education and professional practice instead of centering research on a single model, wasting an interesting potential, would not methodological pluralism be more appropriate?

\section{FINAL CONSIDERATIONS}

The discussion above presented elements that support the claim that some Food Service agents feel unappreciated and begin to direct their activities to search for legitimacy in scientific research. Based on this understanding, we defended methodological plurality in contrast to limiting the methods to the biomedical research model, given the complexity expressed in the field.

However, it is not a simple task to sustain plurality in an environment whose hegemonic view of science is expressed, for example, in the rules of graduate program assessment or research project funding, which value procedures based on nature. To operate in a counter-hegemonic model can imply in other scientific and political challenges and tensions, but can also be profitable in relation to the possibilities of answers to the problems faced in the scope of Food Service, even after acknowledging that not a single proposal will exhaust the reality.

Given that in the short space of an essay some issues were not discussed, two aspects stand out and would be interesting objects of future reflections: a) the fact that prestige, or lack thereof, is measured by rules that are disputed in the field, and b) the fact that the valorization of research cannot be seen as neutral and necessarily positive.

\section{CONTRIBUTORS}

FM CAMPOS, SD PRADO, and FR FERREIRA participated from study conception to the final version of the article. FB KRAEMER helped to construct the text and improve its final version.

\section{REFERE N CES}

1. Bourdieu P. O campo científico. In: Ortiz R, organizador. Sociologia. São Paulo: Ática; 1983. p.122-55.

2. Bourdieu P. Os usos sociais da ciência: por uma sociologia clínica do campo científico. São Paulo: Unesp; 2004.

3. Campos GWS. Saúde pública e saúde coletiva: campo e núcleo de saberes e práticas. Ciênc Saúde Colet. 2000; 5(2):219-30. http://dx.doi.org/10.15 90/S1413-81232000000200002

4. Proença RPC, Sousa AA, Veiros MB, Hering B. Qualidade nutricional e sensorial na produção de refeições. Florianópolis: Editora da UFSC; 2005.

5. Conselho Federal de Nutricionistas. Resolução $n^{\circ}$ 380/2005. Dispõe sobre a definição das áreas de atuação do Nutricionista e suas atribuições. Estabeleceu parâmetros numéricos de referencia, por área de atuação, e dá outras providencias. Brasília: Conselho Federal de Nutricionistas; 2005.

6. Vasconcelos FAG. O nutricionista no Brasil: uma análise histórica. Rev Nutr. 2002; 15(2):127-38. http://dx.doi.org/10.1590/S1415-5273200200 0200001

7. Kac G, Proença RCP, Prado SD. A criação da área Nutrição na Capes. Rev Nutr. 2011; 24(6):905-16. http://dx.doi.org/10.1590/S1415-5273201100 0600011

8. Bosi MLM. A nutrição na concepção científica moderna: em busca de um novo paradigma. Rev Nutr. 1994; 7(1):32-47.

9. Luz MT. Prometeu acorrentado: análise sociológica da categoria produtividade e as condições atuais da vida acadêmica. Physis. 2005; 15(1):39-57. http:// dx.doi.org/10.1590/\$0103-73312005000100003

10. L'Abbate $S$. As políticas de alimentação e nutrição no Brasil. I. Período 1940 a 1964. Rev Nutr. 1988; 1(2):87-138.

11. Fernandes FMB. Considerações metodológicas sobre a técnica da observação participante. In: Mattos RA, Baptista TWF, organizadores. Caminhos para análise das políticas de saúde. Rio de Janeiro: Instituto de Medicina Social; 2011 [acesso 2013 jun 10]. Disponível em: http://www.ims.uerj/ccaps 
12. Comissão Organizadora do Congresso Brasileiro de Alimentação para Coletividade. Oficina de elaboração do consenso em alimentação para coletividade. In: $3^{\circ}$ Congresso Brasileiro de Alimentação para Coletividade. Fortaleza: Instituto de Formação Profissional e Sindical; 2013.

13. Bourdieu P. O poder simbólico. $3^{\mathrm{a}}$ ed. Rio de Janeiro: Bertrand Brasil; 2000.

14. Ypiranga L, GIL MF. Formação profissional do nutricionista: por que mudar? In: Cunha DTO, Ypiranga L, Gil MF, organizadores. II Seminário Nacional sobre o Ensino de Nutrição. Goiânia: Federação Brasileira de Bancos; 1989.

15. Bourdieu P. A distinção: crítica social do julgamento. $2^{a}$ ed. Porto Alegre: Zouk; 2011.

16. Castiel LD, Sanz-Valero J. Entre fetichismo e sobrevivência: o artigo científico é uma mercadoria acadêmica? Cad Saúde Pública. 2007; 23(12):3041-50. http://dx.doi.org/10.1590/S0102-311X200700 1200026

17. Mendonça ALO. Dos valores de medida aos valores como medida: uma avaliação axiológica da avaliação acadêmica. Ensaios Filosóficos. 2014 [acesso 2015 dez 18]; 10:111-33. Disponível em: http://www.ensaiosfilosoficos.com.br/Artigos/ Artigo10/MENDONCA_Andre_Da_Bibliometria_ a_Axiologia.pdf

18. Comissão Científica Nacional do Congresso Brasileiro de Alimentação para Coletividade. Fórum de coordenadores e docentes da área de alimentação para coletividade. In: $3^{\circ}$ Congresso Brasileiro de Alimentação para Coletividade. Fortaleza: Instituto de Formação Profissional e Sindical; 2013.

19. Camargo Junior KR. Produção científica: avaliação da qualidade ou ficção contábil? Cad Saúde Pública. 2013; 29(9):1707-30. http://dx.doi.org/10. 1590/0102-311X00115413

20. Castiel LD, Moraes DR, Silva CSP. O gerencialismo utilitarista na produção acadêmica em saúde coletiva: a importância de ensaios críticos. In: Rede de Pesquisa em Atenção Primária à Saúde. Rio de Janeiro: Associação Brasileira de Saúde Coletiva; 2014 [acesso 2015 abril 20]. Disponível em: http:// www.rededepesquisaaps.org.br/2014/03/10/ogerencialismo-utilitarista-na-producao-academicaem-saude-coletiva-a-importancia-de-ensaioscriticos

21. Akutsu RC. Os nutricionistas brasileiros: perfil profissional e demográfico. Rev Nutr. 2008; 21(1):7-19.
http://dx.doi.org/10.1590/S1415-5273200800 0100002

22. Coordenação de Aperfeiçoamento de Pessoal de Nível Superior. Cursos recomendados. Brasília: Capes; 2014 [acesso 2014 set 4]. Disponível em: http://www.capes.gov.br/cursos-recomendados

23. Bosi MLM. Profissionalização e conhecimento: a nutrição em questão. São Paulo: Hucitec; 1996.

24. Freitas MCS, Minayo MCS, Fontes GAV. Sobre o campo da alimentação e nutrição na perspectiva das teorias compreensivas. Ciênc Saúde Colet. 2011; 16(1):31-8. http://dx.doi.org/10.1590/S14 13-81232011000100008

25. Hahn H, Neurath O, Carnap R. A concepção científica do mundo: o círculo de Viena. Cad Hist Fil Ciênc. 1986; 10:5-20.

26. Popper KR. Em busca de um mundo melhor. São Paulo: Martins Editora; 2006.

27. Kuhn TS. A estrutura das revoluções científicas. $10^{a}$ ed. São Paulo: Perspectiva; 2011.

28. Kraemer FB, Prado SD, Ferreira FR, Carvalho MCVS. O discurso sobre a alimentação saudável como estratégia de biopoder. Physis. 2014; 24(4):1337-60. http://dx.doi.org/10.1590/S0103-73312014000 400016

29. Collins HM. O cientista na rede. In: Collins HM. Mudando a ordem: replicação e indução na prática científica. Belo horizonte: Fabrefactum; 2011.

30. Latour, B. Ciência em ação: como seguir cientistas e engenheiros sociedade afora. São Paulo: Unesp; 2011.

31. Feyerabend P. Contra o método. São Paulo: Unesp; 2007.

32. Lacey H. Ciência, respeito à natureza e bem-estar humano. Sci Stud. 2008; 6(3):297-327. http:// dx.doi.org/10.1590/S1678-31662008000300002

33. Junquilho GS. Gestão e ação gerencial nas organizações contemporâneas: para além do "folclore" e o "fato". Gest Prod. 2001; 8(3):304-18. http:// dx.doi.org/10.1590/S0104-530X2001000300007

34. Morin E. Introdução ao pensamento complexo. $3^{a}$ ed. Porto Alegre: Sulina; 2007.

Received: June 1, 2015 Final version: January 4, 2016 Approved: January 26, 2016 
